\title{
Influence of Temperature Cycles on Bond between Glass Fiber-Reinforced Polymer and Concrete
}

\author{
by Manuel A. G. Silva, Hugo Biscaia, and Carlos Chastre
}

\begin{abstract}
Reinforced concrete $(R C)$ beams externally strengthened with glass fiber-reinforced polymer (GFRP) strips bonded to the soffit may see their load-carrying capacity reduced due to environmental conditions - especially due to the deterioration of bond between the adhesively bonded laminates and concrete, causing premature failure. More research has been published on the detachment of the laminate progressing from the anchorage zone than on failure induced by the formation of flexural or shear-flexural cracks in the midspan followed by fiber-reinforced polymer (FRP) separation and failure designated as intermediate crack (IC) debonding. An experimental program to study degradation of the GFRP laminate beam specimens after accelerated temperature cycles, namely: 1) freezing-and-thawing type; and 2) cycles of the same amplitude $\left(40^{\circ} \mathrm{C}\left[104^{\circ} \mathrm{F}\right]\right)$ and an upper limit approximately $70 \%$ of the glass vitreous transition temperature of the resin, $\mathrm{T}_{\mathrm{g}}$, is described. Effects on the bond stress and ultimate capacity are reported. Substantial differences between shear and bending-induced failure and a decrease of bond stresses and engagement of the laminates on the structural response are analyzed.
\end{abstract}

Keywords: accelerated aging; bond stresses; degradation; glass fiberreinforced polymer; temperature cycles.

\section{INTRODUCTION}

The reliability of fiber-reinforced polymers (FRPs) to strengthen beams and slabs of reinforced concrete (RC) depends on how the stress field develops at the concrete interface with the laminate and ensures the integral response of the structural member. That response essentially depends on the way the transmittal of stress from concrete to the laminate is made and how it is preserved along the expected lifetime of the structure. Ideally, the FRP external strips should remain perfectly bonded to the concrete substrate regardless of the predicted loading and environmental conditions the strengthened structure is subjected to.

Knowledge of the bond mechanisms and their degradation will allow more accurate definition of limits on the use of FRP and ensure safety of the structure without compromising economic criteria. Currently, the technical information on environmental degradation of bond between external reinforcement and substrate material along the lifetime of RC structures strengthened with FRP still requires further studies.

The authors have studied the influence of different environmental agents on the FRP external strengthening of structures, but this paper concentrates solely on effects of temperature variation. Another important aspect not addressed herein is the synergetic effect of moisture, temperature, and/or sustained loading, despite the knowledge that it may be more severe than the separate consequences of each.

Glass fiber-reinforced polymer (GFRP) coupons immersed in distilled water at room temperature and at $60^{\circ} \mathrm{C}\left(140^{\circ} \mathrm{F}\right)$ for up to 5 months showed that for immersion at $60^{\circ} \mathrm{C}\left(140^{\circ} \mathrm{F}\right)$, the peak ultimate strength decayed considerably after 5 months, whereas for immersion at room temperature, the strength actually increased $3 \% .^{2}$ However, the conditions of the tests make the results difficult to apply to structural engineering.

Temperature cycles may modify permeability and alter the presence of highly alkaline pore water in concrete, affecting the durability of the GFRP composite fibers ${ }^{3}$ and causing damage difficult to detect on studies of comparatively short duration.

Effects of freezing-and-thawing cycles on bond durability of carbon fiber-reinforced polymer (CFRP) RC were studied by Green et al. ${ }^{4}$ The study imposed cycles lasting 5000 hours, each defined by 16 hours of freezing in cold air at $-18^{\circ} \mathrm{C}$ $\left(-0.4^{\circ} \mathrm{F}\right)$ followed by 8 hours of thawing in a warm water bath at $+15^{\circ} \mathrm{C}\left(+59^{\circ} \mathrm{F}\right)$. The load-carrying capacity was found unaffected, although the failure modes of the beams at the interface showed slight changes.

Studies on bond of FRP reinforcing bars shed some light on bond that may help the studies for external strengthening. The problem with reinforcing bars differs from that of external reinforcement due to the absence of adhesive in the case of internal reinforcement, as well as not being constrained by insufficient length of bond, but sheds some light on the aging process. For example, Reference 5 shows that the high transverse coefficient of thermal expansion of the GFRP causes bursting in concrete around the reinforcing bars at high temperature. For those cases and conditions, concrete cylinders reinforced with GFRP exhibited the largest reduction in splitting strength, with consequent weakening of bond between the concrete and the GFRP and reduction in the tension stiffening of the concrete.

Experimental results on the effects of temperature on the mechanical properties of GFRP reinforcement reinforcing bars are found in Reference 6. The authors found an increasing loss in strength with the number of cycles, even for small variations of temperature- the loss being smaller than under wet-dry cycles.

Effects of temperature on bond of FRP reinforcing bars are also treated in Reference 7, showing that polymeric material is more flexible than concrete-especially for higher temperatures - as opposed to contact between much stiffer steel and concrete, preventing the use of steel-concrete type of bond-slip models. For FRP bars, the first stage of the

ACI Structural Journal, V. 110, No. 6, November-December 2013.

MS No. S-2011-365.R1 received May 11, 2012, and reviewed under Institute publication policies. Copyright (C) 2013, American Concrete Institute. All rights reserved, including the making of copies unless permission is obtained from the copyright proprietors. Pertinent discussion including author's closure, if any, will be published in the September-October 2014 ACI Structural Journal if the discussion is received by May 1,2014 
Manuel A. G. Silva is a Professor of structural engineering at Universidade Nova de Lisboa Portugal (UNL), Lisbon, Portugal. He received his MSc and PhD from Rice University, Houston, TX, and Northwestern University, Evanston, IL, respectively. His research interests include structural dynamics and durability of reinforced concrete structures with external fiber-reinforced polymer reinforcement.

Hugo Biscaia received his MSc from the Technical University of Lisbon (IST), Lisbon, Portugal, and his PhD from UNL. His research interests include the behavior of reinforced concrete structures strengthened with fiber-reinforced polymer and the degradation of structural capacity caused by environmental factors.

Carlos Chastre is an Assistant Professor of structural engineering at UNL. He received his MSc and PhD from IST and UNL, respectively. His research interests include the strengthening of reinforced concrete structures with fiber-reinforced polymer systems.

Table 1-Average cubic compressive strength

\begin{tabular}{c|c|c|c}
\hline \multirow{2}{*}{ Time, days } & \multicolumn{3}{|c}{$f_{\text {cm }}, \mathrm{MPa}$} \\
\cline { 2 - 4 } & Natural aging & $\begin{array}{c}\text { Cycles }, \\
-10 \text { and }+30^{\circ} \mathrm{C} \\
\left(14 \text { and } 86^{\circ} \mathrm{F}\right)\end{array}$ & $\begin{array}{c}\text { Cycles, } \\
7.5 \text { and } 47.5^{\circ} \mathrm{C}, \\
\left(45.5 \text { and } 117.5^{\circ} \mathrm{F}\right)\end{array}$ \\
\hline 60 & 18.2 & 18.2 & 18.2 \\
\hline 210 & 21.0 & 22.1 & 17.0 \\
\hline 450 & 20.8 & 16.0 & 22.8 \\
\hline
\end{tabular}

Note: $1 \mathrm{MPa}=145.0377$ psi.

load-slip shows a rapid 30 to $40 \%$ reduction of load bearing immediately after the peak, and a more gradual decrease afterwards. Returning to external strengthening, Leone et al. $^{8}$ analyze the interface behavior at elevated service temperatures. The epoxy resin is sensitive to the temperature increase, especially because it cures at relatively low glass transition temperature $T_{g}$. The reduction of $T_{g}$ at relatively high operating temperatures decreases the mechanical properties of the adhesive and modifies the effective bond length and bond strength of the FRP, leading the $f i b$ Bulletin $14^{9}$ to recommend that $T_{g}$ of the adhesive be at least $20^{\circ} \mathrm{C}\left(68^{\circ} \mathrm{F}\right)$ above the maximum ambient temperature at normal service conditions, and larger than $45^{\circ} \mathrm{C}\left(113^{\circ} \mathrm{F}\right)$, a rather low value. The present authors have found cohesive failure at $50^{\circ} \mathrm{C}\left(122^{\circ} \mathrm{F}\right)$ and adhesive failure at the interface for temperatures nearing $80^{\circ} \mathrm{C}\left(176^{\circ} \mathrm{F}\right)$.

Ren et al. ${ }^{10}$ performed freezing-and-thawing tests on concrete structures strengthened with FRP sheets and concluded that the bond strength decreased under those cycles. Fava et al. ${ }^{11}$ imposed temperature cycles to age beams with external FRP plates. The temperature interval used went from -18 to $4^{\circ} \mathrm{C}\left(-0.4\right.$ to $39.2^{\circ} \mathrm{F}$ ), but the cycles of 5 hours each are not clearly described. The authors found reduced bond shear strength and higher deformability of the interface, with a high peak slip. Mukhopadhyaya et al. ${ }^{12}$ recorded the effects of 450 cycles of freezing-and-thawing cycles (two per day) between -17.8 and $20^{\circ} \mathrm{C}\left(-0.04\right.$ and $\left.68^{\circ} \mathrm{F}\right)$. A decrease of $3.3 \%$ on the ultimate load at failure was found in double shear type of tests for the samples made of $37.1 \mathrm{MPa}$ (5.38 ksi) concrete strength at 28 days, and an average rise of $10.7 \%$ for the specimens made of $48.6 \mathrm{MPa}$ (7.05 ksi) concrete. ${ }^{12}$ Bond stresses were on average lower $12.6 \%$ in the first case, against a decrease of $24.7 \%$ in the latter and the bond transfer length increased. These results imply that the effects on concrete itself are important on the behavior of the carbon fiber-reinforced polymer (CFRP) strengthened structures under freezing-and-thawing tests, the same being expected for GFRP. The failure modes found were essentially adhesive. This is different from other reported cases in the literature, ${ }^{13}$ perhaps, because, in the latter, the ultimate tensile stress of concrete was higher than that of the adhesive resin.

\section{RESEARCH SIGNIFICANCE}

Data on the performance of beams externally strengthened with FRP over time are required to design and assess durability of those systems. Deterioration of adhesively bonded joints FRP/concrete can cause premature failure of slabs and beams and is influenced by temperature cycles, with different mechanisms of failure triggered at different mean temperatures. Tests of specimens submitted to accelerated thermal cycles contribute to lessen the paucity of available results and are reported. Both flexural and shear diagonal crack induced failures are examined. Results are expected to contribute to better understanding of bond slip for each thermal environmental condition and stress field.

\section{Materials}

\section{EXPERIMENTAL PROGRAM}

Tests of mechanical strength were made both on GFRP flat coupons and on small beam specimens strengthened with external strips of GFRP. A commercial composite was acquired for the study. The sheets are weaved and made of one-directional longitudinal fibers of E-glass, crossed by a sparse distribution of aramidic fibers unintended for strength, with a fiber dry mass density $0.915 \mathrm{~kg} / \mathrm{m}^{3}\left(3.306 \times 10^{-5} \mathrm{lb} /\right.$ in. ${ }^{3}$ ) per ply (design ply thickness of $1.27 \mathrm{~mm}$ [0.05 in.]). The dry fiber tensile strength and the longitudinal modulus $E$ according to the supplier are $3.24 \mathrm{GPa}(469,922.3 \mathrm{psi})$, $72.4 \mathrm{GPa}\left(1.050 \times 10^{7} \mathrm{psi}\right)$, respectively. For the epoxy resin, the supplier indicated $72.4 \mathrm{MPa}(10,500.73 \mathrm{psi})$ for tensile strength, $E=3.18 \mathrm{GPa}(461,220 \mathrm{psi}), 123.4 \mathrm{MPa}$ $(17,897.66 \mathrm{psi})$ for flexural strength and a $T_{g}$ of $82^{\circ} \mathrm{C}\left(179.6^{\circ} \mathrm{F}\right)$ after a cure of 24 hours at $60^{\circ} \mathrm{C}\left(71.6^{\circ} \mathrm{F}\right)$. Mechanical properties of concrete were obtained experimentally.

Low-strength concrete was made to approximate actual conditions requiring rehabilitation and the evolution of its compressive strength along time is shown in Table 1. Tests were made in $150 \mathrm{~mm}$ (5.905 in.) cubes, three at each stage of selected periods of aging, for each type of cycle. Average natural aging temperature was $21.6^{\circ} \mathrm{C}\left(70.9^{\circ} \mathrm{F}\right)$ and relative humidity was $61.6 \%$.

\section{Artificial aging}

The programs of the two types of imposed temperature cycles on climatic chambers defined cycles of 24 hours with two constant temperatures applied for 12 hours each, and pre-set transition time to avoid sudden thermal variation. The case on which the temperature levels were -10 and $+30^{\circ} \mathrm{C}$ ( 14 and $86^{\circ} \mathrm{F}$ ) is designated henceforth by the freezing-andthawing cycle, has an average temperature of $+10^{\circ} \mathrm{C}\left(50^{\circ} \mathrm{F}\right)$ and a wide thermal amplitude of $40^{\circ} \mathrm{C}\left(104^{\circ} \mathrm{F}\right)$. The other cycles are defined by 7.5 and $47.5^{\circ} \mathrm{C}\left(45.5\right.$ and $\left.117.5^{\circ} \mathrm{F}\right)$ and were designed to compare the behavior for the same thermal amplitude, different mean values $\left(10\right.$ and $27.5^{\circ} \mathrm{C}$ [50 and $\left.81.5^{\circ} \mathrm{F}\right]$ ), one of the cycles imposing negative temperatures. The choice of the upper limit $47.5^{\circ} \mathrm{C}\left(117.5^{\circ} \mathrm{F}\right)$ was as close to $T_{g}$ as feasible due to a temporary limitation with available equipment. The cycles were imposed up to 10,000 hours. The beams had been cast for 190 days when their artificial aging started. 
Both flat coupons of GFRP and RC specimens reinforced with GFRP were submitted to cycles of the same type. The times chosen to remove the coupons from the chambers and evaluate the eventual degradation of their mechanical properties were 3000, 5000 and 10,000 hours, the same stages used previously by two of the authors on aging of flat coupons of GFRP ${ }^{14}$ and of polymeric mortar prisms.

\section{FLAT COUPONS-AGING AND MECHANICAL PROPERTIES}

The GFRP laminates had the relative mass content of resin and fiber determined by submitting samples to high temperature, around $600^{\circ} \mathrm{C}\left(1112^{\circ} \mathrm{F}\right)$, in an oven and comparing their weights before and after "burning" the resin. The average mass percentage of glass fiber found was $62.1 \%$, with $37.9 \%$ of epoxy. Coupons of $250 \times 25 \mathrm{~mm}$ (9.842 x 0.984 in.) were cut from GFRP laminate plates and tabs approximately $3 \mathrm{~mm}$ (0.118 in.) thick, $40 \mathrm{~mm}$ (1.575 in.) long were glued on each side of the flat coupons, at both ends, to avoid failure caused by stress concentration near the jaws of the universal testing machine of $50 \mathrm{kN}$ (11.24 kip) capacity used. Tests were displacement-controlled at a rate of $0.01 \mathrm{~mm} / \mathrm{s}\left(3.937 \times 10^{-4} \mathrm{in} . / \mathrm{s}\right)$ following ASTM D3039/ D3039M. ${ }^{15}$ Twenty-two flat coupons were tested, four of which at the start time for temperature conditioning, designated as 0 hours. The reference mechanical properties obtained are shown in Table 2, whereas the values after aging are displayed in Tables 3 and 4. For the cycle with an average temperature of $27.5^{\circ} \mathrm{C}\left(81.5^{\circ} \mathrm{F}\right)$, slip of the tabs caused readings in error and no value at 5000 hours was considered reliable.

An indicator $r_{C}\left(t_{a}\right)$ is adopted to measure the degree of degradation of property $C(t)$ experienced by the coupons from the beginning of aging, at $t_{o}$, to the corresponding value at $t_{a}$. This coefficient $r$, function of time, that is, $r_{C}\left(t_{a}\right)$, is obtained dividing $C\left(t_{a}^{G}\right)$, the value of the corresponding ultimate value after $t_{a}$ hours of aging, by the value $C\left(t_{0}\right)$ of the same quantity at the start of aging. In percentage

Table 2-Mechanical properties of GFRP laminates before aging

\begin{tabular}{|c|c|c|c|c|c|c|}
\hline & $\varepsilon_{f}, \%$ & $\varepsilon_{f m}, \%$ & $f_{f}, \mathrm{MPa}$ & $f_{f m}, \mathrm{MPa}$ & $E_{f}, \mathrm{MPa}$ & $E_{f m}, \mathrm{MPa}$ \\
\hline REF-01 & 2.25 & \multirow{4}{*}{2.20} & 487.2 & \multirow{4}{*}{513.9} & 22.14 & \multirow{4}{*}{23.49} \\
\hline REF-02 & 2.20 & & 507.5 & & 23.09 & \\
\hline REF-03 & 2.14 & & 551.1 & & 25.78 & \\
\hline REF-04 & 2.22 & & 509.9 & & 22.96 & \\
\hline
\end{tabular}

$$
r_{C}=r_{C}\left(t_{a}\right)=100 \frac{C\left(t_{a}\right)}{C\left(t_{0}\right)}
$$

The cycles at temperature averaging $27.5^{\circ} \mathrm{C}\left(81.5^{\circ} \mathrm{F}\right)$ led to a $15.9 \%$ larger ultimate strain measured in the strain gauges and a loss of the average tensile strength of $4.6 \%$ at 3000 hours. Change of stress is minimal, but the increase of strain and reduction of axial deformability is significant. At 10,000 hours, the tensile strength remained without further change, while the value of the strain is smaller than at 3000 hours and still higher than for the reference coupons. The latter differences are relatively small and generalization would require more data.

The results of the mechanical tests after the freezing-andthawing cycles of the same amplitude - that is, -10 and $+30^{\circ} \mathrm{C}$ (14 and $86^{\circ} \mathrm{F}$ ), are displayed in Table 4 and show, again, a substantial increase of ultimate strain at 3000 hours $(18.2 \%)$ for a tensile stress at failure that has the same value as in the reference coupons. Both properties decrease at 5000 hours and approach the reference values at 10,000 hours. The results point to an initial greater deformability that is lost in time.

The modification of the glass vitreous temperature $T_{g}$ due to both types of cycles is displayed in Table 5. The differential scanning calorimetry, abbreviated as DSC, was used instead of the dynamic mechanical thermal analysis (DMTA) used in previous research. DMTA also imposes a mechanical deformation, and $T_{g}$ obtained by DSC may be $15^{\circ} \mathrm{C}\left(59^{\circ} \mathrm{F}\right)$ or more below the value found by DMTA, depending on parameters used and materials studied. ${ }^{16}$ The DSC procedure was applied heating the samples from 25 to $100^{\circ} \mathrm{C}$ (77 to $\left.212^{\circ} \mathrm{F}\right)$ at a constant rate of $5^{\circ} \mathrm{C} / \mathrm{min}\left(41^{\circ} \mathrm{F} / \mathrm{min}\right)$, stabilizing the temperature at $100^{\circ} \mathrm{C}\left(212^{\circ} \mathrm{F}\right)$ for 3 minutes and lowering the temperature back to $25^{\circ} \mathrm{C}\left(77^{\circ} \mathrm{F}\right)$ at a negative rate of $5^{\circ} \mathrm{C} / \mathrm{min}\left(41^{\circ} \mathrm{F} / \mathrm{min}\right)$. The measurements were taken both for increasing and decreasing temperature, but the values used correspond to those found for increasing temperatures. The results indicate that the curing of the polymeric matrix at the onset of artificial aging (average $T_{g}=61^{\circ} \mathrm{C}\left[T_{g}=\right.$ $\left.141.8^{\circ} \mathrm{F}\right]$ ) was incomplete, while at 3000 hours, a higher $T_{g}$ was reached, reflecting that further cure of the resin, at that stage, prevailed over simultaneous deleterious effects from aging. From there on, the aging process kept lowering the glass vitreous temperature, which stayed, nevertheless, sufficiently higher than the highest temperatures imposed on the specimens.

An earlier study on GFRP coupons ${ }^{14}$ with $T_{g}$ of $66^{\circ} \mathrm{C}$ $\left(150.8^{\circ} \mathrm{F}\right)$ at 0 hours subjected the coupons to step cycles

Table 3-Mechanical properties of GFRP laminates after aging cycles 7.5 and $47.5^{\circ} \mathrm{C}\left(45.5\right.$ and $\left.117.5^{\circ} \mathrm{F}\right)$

\begin{tabular}{|c|c|c|c|c|c|c|c|c|c|c|}
\hline \multirow[b]{2}{*}{ Coupon label } & \multirow{2}{*}{$\frac{\text { Aging }}{t_{a}, \text { hours }}$} & \multicolumn{2}{|c|}{ Ultimate strains } & \multirow{2}{*}{$\begin{array}{c}\text { Strain retention } \\
r_{\varepsilon}, \% \\
\end{array}$} & \multicolumn{2}{|c|}{ Ultimate stresses } & \multirow{2}{*}{$\begin{array}{c}\text { Stress retention } \\
r_{f}, \%\end{array}$} & \multicolumn{2}{|c|}{ Elastic modulus } & \multirow{2}{*}{$\begin{array}{c}\text { Modulus retention } \\
r_{E}, \%\end{array}$} \\
\hline & & $\varepsilon_{f}, \%$ & $\varepsilon_{f m}, \%$ & & $f_{f}, \mathrm{MPa}$ & $f_{f m}, \mathrm{MPa}$ & & $E_{f}, \mathrm{MPa}$ & $E_{f m}, \mathrm{MPa}$ & \\
\hline 7.5 to $47.5-01$ & \multirow{3}{*}{3000} & 2.57 & \multirow{3}{*}{2.55} & \multirow{3}{*}{115.9} & 507.0 & \multirow{3}{*}{490.1} & \multirow{3}{*}{95.4} & 19.76 & \multirow{3}{*}{19.24} & \multirow{3}{*}{81.9} \\
\hline 7.5 to $47.5-02$ & & 2.42 & & & 450.0 & & & 18.59 & & \\
\hline 7.5 to $47.5-03$ & & 2.65 & & & 513.3 & & & 19.36 & & \\
\hline 7.5 to $47.5-07$ & \multirow{3}{*}{10,000} & 2.35 & \multirow{3}{*}{2.30} & \multirow{3}{*}{104.6} & 502.5 & \multirow{3}{*}{494.1} & \multirow{3}{*}{96.2} & 21.39 & \multirow{3}{*}{21.53} & \multirow{3}{*}{91.7} \\
\hline 7.5 to $47.5-08$ & & 2.26 & & & 485.7 & & & 21.55 & & \\
\hline 7.5 to $47.5-09$ & & $1.98^{*}$ & & & 427.9 & & & 21.64 & & \\
\hline
\end{tabular}

"Value affected by slip of tabs

Note: $1 \mathrm{MPa}=145.0377$ psi. 
Table 4-Mechanical properties of GFRP laminates after aging cycles -10 and $30^{\circ} \mathrm{C}\left(14\right.$ and $\left.86^{\circ} \mathrm{F}\right)$

\begin{tabular}{|c|c|c|c|c|c|c|c|c|c|c|}
\hline \multirow[b]{2}{*}{ Coupon label } & \multirow{2}{*}{$\begin{array}{c}\text { Aging } \\
t_{a} \text {, hours }\end{array}$} & \multicolumn{2}{|c|}{ Ultimate strains } & \multirow{2}{*}{$\begin{array}{c}\text { Strain retention } \\
r_{\varepsilon}\left(t_{a}\right), \%\end{array}$} & \multicolumn{2}{|c|}{ Ultimate stresses } & \multirow{2}{*}{$\begin{array}{c}\text { Stress retention } \\
r_{f}\left(t_{a}\right), \%\end{array}$} & \multicolumn{2}{|c|}{ Elastic modulus } & \multirow{2}{*}{$\begin{array}{c}\text { Modulus retention } \\
r_{E}\left(t_{a}\right), \%\end{array}$} \\
\hline & & $\varepsilon_{f}, \%$ & $\varepsilon_{f m}, \%$ & & $f_{f}, \mathrm{MPa}$ & $f_{f i n}, \mathrm{MPa}$ & & $E_{f}, \mathrm{MPa}$ & $E_{f m}, \mathrm{MPa}$ & \\
\hline-10 to $30-01$ & \multirow{3}{*}{3000} & 2.53 & \multirow{3}{*}{2.60} & \multirow{3}{*}{118.2} & 522.4 & \multirow{3}{*}{513.0} & \multirow{3}{*}{99.8} & 20.67 & \multirow{3}{*}{19.76} & \multirow{3}{*}{84.1} \\
\hline-10 to $30-02$ & & 2.66 & & & 504.7 & & & 19.00 & & \\
\hline-10 to $30-03$ & & 2.61 & & & 512.0 & & & 19.61 & & \\
\hline-10 to $30-04$ & \multirow{3}{*}{5000} & 2.20 & \multirow{3}{*}{2.03} & \multirow{3}{*}{92.3} & 461.3 & \multirow{3}{*}{433.0} & \multirow{3}{*}{84.3} & 21.01 & \multirow{3}{*}{21.35} & \multirow{3}{*}{90.9} \\
\hline-10 to $30-05$ & & 1.85 & & & 393.2 & & & 21.23 & & \\
\hline-10 to $30-06$ & & 1.86 & & & 404.8 & & & 21.81 & & \\
\hline-10 to $30-07$ & \multirow{3}{*}{10,000} & 2.22 & \multirow{3}{*}{2.21} & \multirow{3}{*}{100.5} & 491.5 & \multirow{3}{*}{485.7} & \multirow{3}{*}{94.5} & 22.11 & \multirow{3}{*}{21.33} & \multirow{3}{*}{90.8} \\
\hline-10 to $30-08$ & & 2.20 & & & 479.9 & & & 21.81 & & \\
\hline-10 to $30-09$ & & $1.45^{*}$ & & & $291.1^{*}$ & & & 20.06 & & \\
\hline
\end{tabular}

"Unreliable datum and neglected in analysis.

Note: $1 \mathrm{MPa}=145.0377 \mathrm{psi}$.

Table 5-Glass vitreous transition temperature $T_{g}$ by DSC

\begin{tabular}{c|c|c|c}
\hline \multicolumn{2}{c|}{} & $\begin{array}{c}T_{g}\left({ }^{\circ} \mathrm{C}\right) \\
\text { increasing } \\
\text { temperature }\end{array}$ & $\begin{array}{c}T_{g}\left({ }^{\circ} \mathrm{C}\right) \\
\text { decreasing } \\
\text { temperature }\end{array}$ \\
\hline \multirow{3}{*}{$\begin{array}{c}\text { Tycles } 7.5 \text { and } 47.5^{\circ} \mathrm{C} \\
\left(45.5 \text { and } 117.5^{\circ} \mathrm{F}\right)\end{array}$} & 5000 & 68.1 & 65.9 \\
\cline { 2 - 4 } & 10,000 & 67.3 & 61.8 \\
\hline \multirow{3}{*}{$\begin{array}{c}\text { Cycles }-10 \text { and } 30^{\circ} \mathrm{C} \\
\left(14 \text { and } 86^{\circ} \mathrm{F}\right)\end{array}$} & 3000 & 70.3 & 60.5 \\
\cline { 2 - 4 } & 5000 & 75.8 & 60.5 \\
\cline { 2 - 4 } & 10,000 & 71.6 & 63.2 \\
\hline
\end{tabular}

(20 and $50^{\circ} \mathrm{C}$ [ 68 and $\left.122^{\circ} \mathrm{F}\right]$ ), at $80 \%$ relative humidity and led to the results shown in Table 6. Again, from 3000 to 10,000 hours, a constant increase of the retention coefficient of the ultimate strain is observed, reaching a final average value of $99 \%$ of the strain found on the control specimens. The tensile strength showed a loss of approximately $6.7 \%$ at 3000 hours, a decrease reduced to less than $5 \%$ at the later stages, comparable to the results reported for 7.5 and $47.5^{\circ} \mathrm{C}$ (45.5 and $\left.117.5^{\circ} \mathrm{F}\right)$.

It may be summarized from the reported tests that:

- Temperature cycles, with an upper limit near $80 \%$ of $T_{g}$, increase the axial deformability of the GFRP coupons up to $16 \%$, and slightly lower the ultimate tensile strength;

- The tensile strength retention is of the same order of magnitude for both temperature cycles varying around $95 \%$; and

- In both types of aging tests, a non-negligible degradation of the elastic modulus is observed. At 3000 hours, the reduction is between 16 and $18 \%$, while at 10,000 hours, the reduction is approximately $9 \%$.

\section{DEGRADATION OF CAPACITY OF BEAMS DUE TO TEMPERATURE CYCLES}

Twenty-four small beams were tested with the geometry and the reinforcement (A400 steel bars), as shown in Fig. 1. The soffit of the beams had a small notch at the midspan to cause a discontinuity on the bonding of the strip of FRP used to strengthen the beams. The steel reinforcement had an average stress $f_{0.2 m}=406 \mathrm{MPa}(58,885 \mathrm{psi})$ at the conventional strain of $0.2 \%$ and an ultimate tensile stress $f_{t m}=649 \mathrm{MPa}(94,129 \mathrm{psi})$.

Externally, strips of two layers of GFRP, either of width $w=80 \mathrm{~mm}$ (3.150 in.) or $w=20 \mathrm{~mm}(0.787 \mathrm{in}$.), were used to strengthen the soffit of the RC beams between supports. Failure due to bending resulted for strips of $w=20 \mathrm{~mm}$ (0.787 in.), while those of $\mathrm{w}=80 \mathrm{~mm}$ (3.150 in.) increased the ultimate load and caused the beams to fail after formation of diagonal shear cracks.

The treatment of the surface previous to bonding of the GFRP strips to the concrete was made by sand blasting under a pressure of No. 4 bar (58.015 psi).

\section{Control RC beams}

Control beams were fabricated both with and without external GFRP strips. The beams were subjected to threepoint load bending tests until collapse and the main results are displayed in Table 7.

Figure 2 illustrates the failure of the beams. For the specimens with the $20 \mathrm{~mm}$ (0.787 in.) strip, the rupture mode was associated with separation of the strip along the interface, after the formation of typical bending cracks. In the case of the $80 \mathrm{~mm}$ (3.150 in.) strip, failure appeared after the formation of a typical shear-bending crack a bit off center that ultimately caused the separation of the strip. This is typically the case of debonding due to intermediate cracking (IC debonding).

Table 7 summarizes the average values found for the load capacity of the beams, $F_{\max }$, and the maximum measured strains $\varepsilon_{\max }$ for the three cases of reference specimens: 1 ) no external GFRP; 2) a strip of width $80 \mathrm{~mm}$ (3.150 in.); or 3) $20 \mathrm{~mm}$ ( $0.787 \mathrm{in}$.). The location where maximum strains $\varepsilon_{\max }$ were measured corresponds to the maximum axial stresses shown in Fig. 3 to 5 and can be linked to the strain gauge identified on the top of the graphs.

The maximum bond stresses $\tau_{\max }$ were determined from the gauges attached to the GFRP

$$
\tau_{\max }=\frac{\Delta \varepsilon \cdot E_{f} \cdot t_{f}}{\Delta L}
$$

where $\Delta \varepsilon$ is the difference of strain obtained from the readings of consecutive strain gauges distant $\Delta L ; t_{f}$ is the thickness; and $E_{f}$ is the elastic modulus of the GFRP 
Table 6-Flat coupons with $T_{g}(\mathrm{DMTA})$ of $66^{\circ} \mathrm{C}\left(150.8^{\circ} \mathrm{F}\right)$. Average tensile properties. Thermal cycles 20 and 50$)^{\circ} \mathrm{C}\left(68 \text { and } 122^{\circ} \mathrm{F}\right)^{15}$

\begin{tabular}{c|c|c|c|c|c|c}
\hline Aging & Ultimate strain & Strain retention & Ultimate stress & Stress retention & Elastic modulus & Modulus retention \\
\hline$t_{a}$, hours & $\varepsilon_{f m}, \%$ & $r_{\varepsilon} \%$ & $f_{f m}, \mathrm{MPa}$ & $r_{f} \%$ & $E_{f m}$, MPa & $r_{E}, \%$ \\
\hline 0 & 2.42 & - & 496 & - & 20.5 & - \\
\hline 3000 & 2.08 & 85.9 & 463 & 93.3 & 22.3 & 108.8 \\
\hline 5000 & 2.37 & 97.9 & 482 & 97.2 & 20.3 & 99.0 \\
\hline 10,000 & 2.39 & 98.8 & 473 & 95.4 & 9.8 & 96.6 \\
\hline
\end{tabular}

Note: $1 \mathrm{MPa}=145.0377 \mathrm{psi}$.

Table 7-Maximum recorded external load and laminate strain, laminate, and bond stress for control beams

\begin{tabular}{|c|c|c|c|c|c|}
\hline Beam & $F_{\max }, \mathrm{kN}$ & $\varepsilon_{\max }, \%$ & $\sigma_{\max }, \mathrm{MPa}$ & $\tau_{\max }, \mathrm{MPa}$ & Observations \\
\hline REF -01 & 17.09 & \multirow{2}{*}{\multicolumn{3}{|c|}{-}} & \multirow{2}{*}{ No GFRP } \\
\hline REF -02 & 18.07 & & & & \\
\hline REF 80-01 shear & 32.82 & 0.51 & 118.59 & 2.80 & \multirow{2}{*}{$80 \mathrm{~mm}$ strips } \\
\hline REF 80-02 shear & 28.65 & 0.29 & 68.77 & 1.69 & \\
\hline REF $20-03$ bending & 25.23 & 1.14 & 267.66 & 6.79 & \multirow{2}{*}{$20 \mathrm{~mm}$ strips } \\
\hline REF $20-04$ bending & 22.36 & 1.11 & 259.93 & 6.20 & \\
\hline
\end{tabular}

Notes: $1 \mathrm{MPa}=145.0377 \mathrm{psi} ; 1 \mathrm{~mm}=0.03937 \mathrm{in}$.

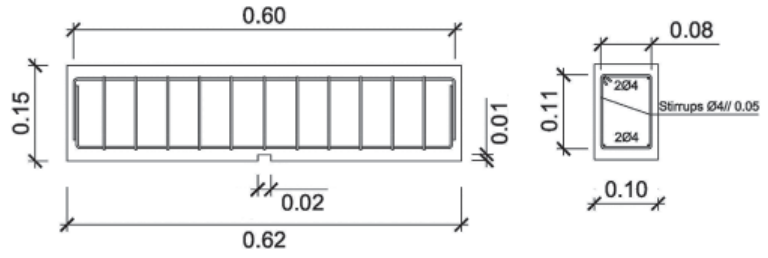

Fig. 1-Geometry and steel reinforcement of small beam specimens. (Dimensions in meters; $1 \mathrm{~m}=39.37 \mathrm{in}$.)

(a) Shear cracking

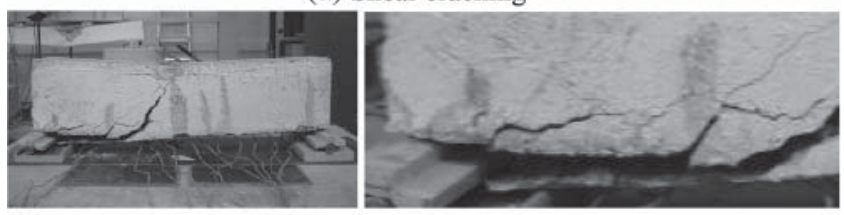

(b) Central bending crack

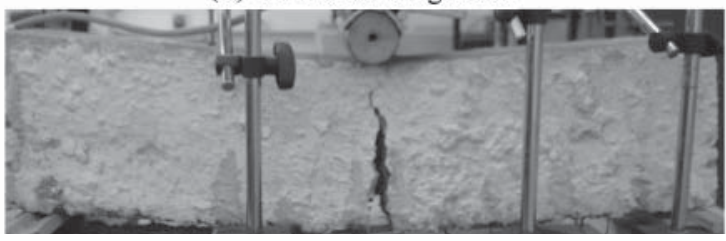

Fig. 2-Failure modes: (a) shear-type cracking $(80 \mathrm{~mm}$ [3.150 in.] strips); and (b) flexural cracking $(20 \mathrm{~mm}$ [0.787 in.] strips).

laminate. The longitudinal stress on the laminate, $\sigma_{\max }$, was calculated from

$$
\sigma_{\text {max }}=\varepsilon_{\text {max }} \cdot E_{f}
$$

where $\varepsilon_{\text {max }}$ is the maximum measured strain.

The average increase of the load-carrying capacity $F_{\max }$ for beams with the GFRP reinforcement strip of $w=20 \mathrm{~mm}$ ( 0.787 in.), over that of the reference beams, was $34 \%$. The
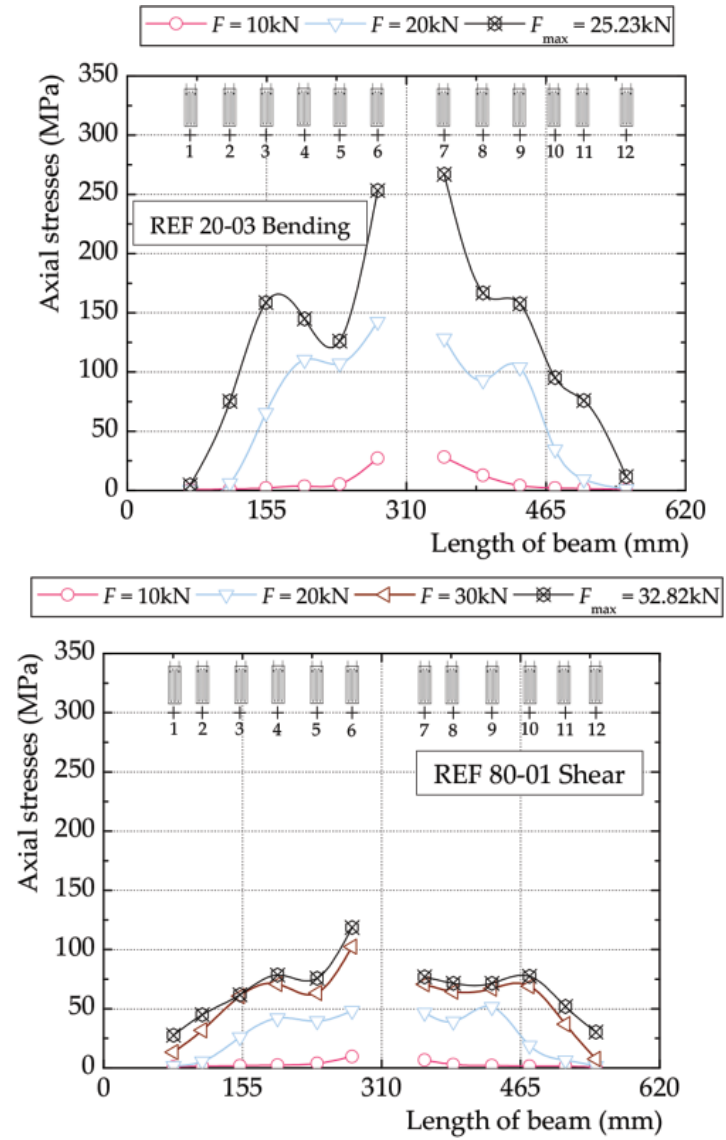

Fig. 3-Axial stress on GFRP for 20 and $80 \mathrm{~mm}(0.787$ and $3.150 \mathrm{in}$.) strips for increasing transversal loading of beams. Reference beams. (Note: $1 \mathrm{MPa}=145.0377 \mathrm{psi} ; 1 \mathrm{~mm}=$ 0.03937 in.)

beams with an external strip $80 \mathrm{~mm}$ (3.150 in.) wide showed a shear-type induced failure and an increase of load capacity of $74 \%$, over that of the beams without external GFRP, at a cost four times the GFRP quantity of material. In an 

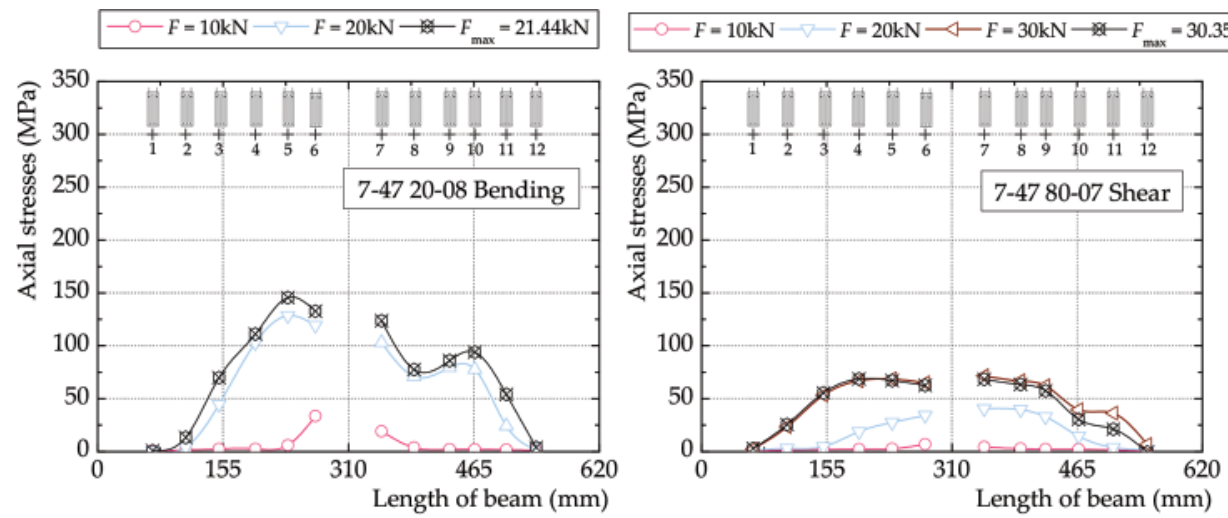

Fig. 4-Axial stress on GFRP for 20 and $80 \mathrm{~mm}$ (0.787 and $3.150 \mathrm{in}$.) strips for increasing external loading of beams. Cycles 7.5 and $47.5^{\circ} \mathrm{C}\left(45.5\right.$ and $\left.117.5^{\circ} \mathrm{F}\right)$ at 10,000 hours. (Note: $1 \mathrm{MPa}=145.0377 \mathrm{psi} ; 1 \mathrm{~mm}=0.03937$ in.)
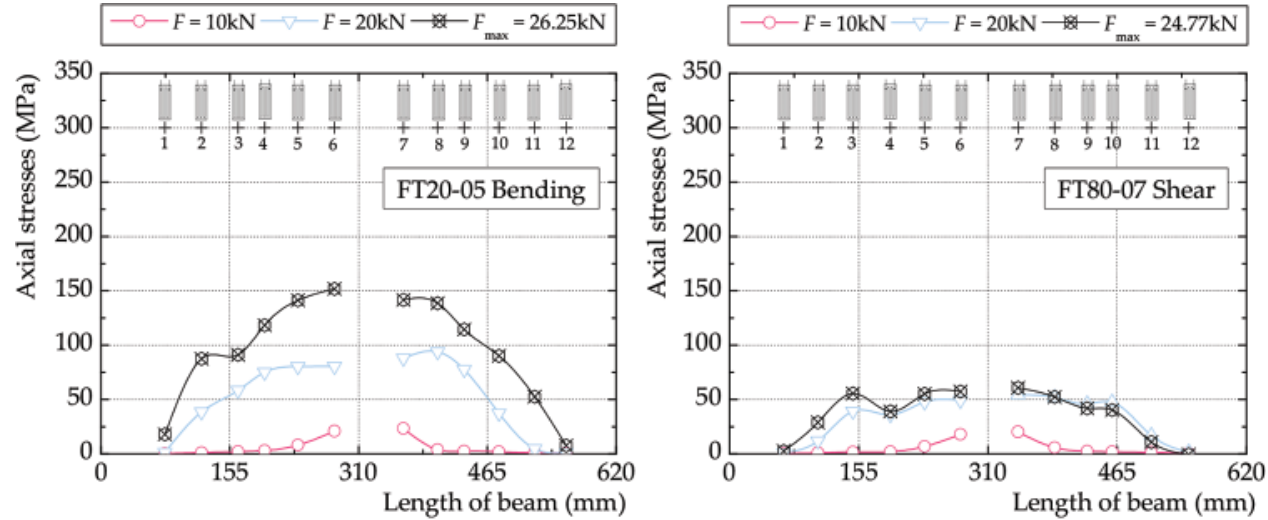

Fig. 5-Axial stress on GFRP for 20 and $80 \mathrm{~mm}$ (0.787 and $3.150 \mathrm{in.}$ ) strips for increasing external loading of beams. Cycles -10 and $+30^{\circ} \mathrm{C}\left(14\right.$ and $\left.86^{\circ} \mathrm{F}\right)$ at 10,000 hours.

(Note: $1 \mathrm{MPa}=145.0377 \mathrm{psi} ; 1 \mathrm{~mm}=0.03937 \mathrm{in}$.)

Table 8-Beams capacity after aging cycles 7.5 and $47.5^{\circ} \mathrm{C}\left(45.5\right.$ and $\left.117.5^{\circ} \mathrm{F}\right)$

\begin{tabular}{|c|c|c|c|c|c|}
\hline $\begin{array}{c}\text { Beam } \\
\text { (temperature range-width-number) }\end{array}$ & Aging, hours & $F_{\max }, \mathrm{kN}$ & $\varepsilon_{\max }, \%$ & $\sigma_{\max }, \mathrm{MPa}$ & $\tau_{\max }, \mathrm{MPa}$ \\
\hline 7 to $4780-01$ & 3000 & 27.35 & 0.32 & 61.27 & 1.75 \\
\hline 7 to $4780-02$ & 3000 & 24.61 & 0.29 & 55.58 & 1.67 \\
\hline 7 to $4780-03$ & 3000 & 27.89 & 0.29 & 60.91 & 1.46 \\
\hline 7 to $4780-07$ & 10,000 & 30.35 & 0.34 & 73.42 & 1.82 \\
\hline 7 to $4780-09$ & 10,000 & 22.43 & 0.44 & 94.06 & 2.36 \\
\hline 7 to $4720-04$ & 3000 & 20.92 & 0.92 & 177.33 & 5.20 \\
\hline 7 to $4720-05$ & 10,000 & 24.64 & 0.60 & 129.96 & 5.87 \\
\hline $7-47$ 20-06 & 10,000 & 26.53 & 0.70 & 149.77 & 4.04 \\
\hline 7-47 20-08 & 10,000 & 21.44 & 0.68 & 145.61 & 3.90 \\
\hline
\end{tabular}

Notes: $1 \mathrm{kN}=224.809 \mathrm{lb} ; 1 \mathrm{MPa}=145.0377$ psi.

actual case where shear-type behavior would be expected, additional shear external reinforcement with GFRP would have been considered.

\section{Results of tests after aging}

The three-point bending tests performed at different stages of the aging processes have the maximum recorded external load, laminate strain and stress, and bond stress values summarized in Tables 8 and 9, respectively, for the 7.5 and $47.5^{\circ} \mathrm{C}\left(45.5\right.$ and $\left.117.5^{\circ} \mathrm{F}\right)$ and the freezing-andthawing cycles.
The degradation of properties can be quantified calculating the relative change of the average values in Tables 8 and 9 from those of the control specimens, shown in Table 7. In the case of shear crack-induced failure at 10,000 hours, the average loss was from 30.73 to $26.39 \mathrm{kN}(6883.52$ to $5911.36 \mathrm{lbf}$ ) - that is, $14.1 \%$ for the 7.5 and $47.5^{\circ} \mathrm{C}\left(45.5\right.$ and $\left.117.5^{\circ} \mathrm{F}\right)$ cycles. At 3000 hours, the average value found for degradation of capacity was very similar. For bending-type failure, $w=20 \mathrm{~mm}$ (0.787 in.), and 7.5 and $47.5^{\circ} \mathrm{C}\left(45.5\right.$ and $\left.117.5^{\circ} \mathrm{F}\right)$ cycles, the changes in the average values ranged from 23.80 to $24.20 \mathrm{k} \mathrm{N}$ at 
Table 9-Beams' capacity after aging cycles -10 and $30^{\circ} \mathrm{C}\left(14\right.$ and $\left.86^{\circ} \mathrm{F}\right)$

\begin{tabular}{|c|c|c|c|c|c|}
\hline $\begin{array}{c}\text { Beam } \\
\text { FT }=\text { freezing and thawing width }- \text { number }\end{array}$ & Aging, hours & $F_{\max }, \mathrm{kN}$ & $\varepsilon_{\max }, \%$ & $\sigma_{\max }, \mathrm{MPa}$ & $\tau_{\max }, \mathrm{MPa}$ \\
\hline FT80-01 & 3000 & 29.59 & 0.36 & 71.19 & 1.75 \\
\hline FT80-02 & 3000 & 28.79 & 0.31 & 61.43 & 1.50 \\
\hline FT80-03 & 3000 & 23.49 & 0.36 & 70.90 & 1.59 \\
\hline FT80-07 & 10,000 & 24.77 & 0.32 & 68.39 & 1.86 \\
\hline FT20-04 & 3000 & 24.31 & 1.20 & 230.58 & 4.82 \\
\hline FT20-05 & 10,000 & 26.25 & 0.71 & 151.73 & 4.07 \\
\hline FT20-06 & 10,000 & 25.44 & 0.72 & 153.99 & 3.92 \\
\hline FT20-08 & 10,000 & 25.92 & 1.18 & 252.28 & 8.01 \\
\hline FT20-09 & 10,000 & 23.65 & 0.92 & 194.92 & 6.54 \\
\hline
\end{tabular}

Notes: $1 \mathrm{kN}=224.809 \mathrm{lb} ; 1 \mathrm{MPa}=145.038$ psi.

10,000 hours - that is, less than a $2 \%$ increase, negligible within the scatter for this type of tests. The maximum strain shows a non-negligible change of average value from $1.1 \%$ to less than $0.7 \%$ at 10,000 hours.

Freezing-and-thawing cycles in Table 9 lead to average values of $25.32 \mathrm{kN}(5671.68 \mathrm{lbf})$ at 10,000 hours, with $24.31 \mathrm{kN}(5445.44 \mathrm{lbf})$ at 3000 hours, for the specimens failing in bending. These values compare with $23.80 \mathrm{kN}(5331.20 \mathrm{lbf})$ for the control beams, showing a slight improvement. In terms of maximum strain, the case of bending-induced failure, $w=20 \mathrm{~mm}(0.787 \mathrm{in}$.), showed a reduction at 10,000 hours averaging from 1.13 to $0.88 \%$.

In the case of failure induced by diagonal cracking, $w=80 \mathrm{~mm}$ (3.150 in.), the freezing-and-thawing aging significantly lowered the capacity of the beams. Using average values calculated from Tables 7 and 9, the average value for $F_{\max }$ in the control beams, $30.73 \mathrm{kN}(5331.20 \mathrm{lbf})$, compared with $27.29 \mathrm{kN}(6112.96 \mathrm{lbf})$ at 3000 hours and $24.77 \mathrm{kN}(5548.48 \mathrm{lbf})$ at 10,000 hours for the single test that could be used. The corresponding maximum relative reduction of load capacity is $11.2 \%$ at 3000 hours and would be $19 \%$ if calculated for the single test at 10,000 hours.

\section{Axial forces carried by GFRP reinforcement}

The axial forces on the laminate decrease toward the supports, with part of the resisting forces carried at the interface and transmitted to the concrete. The axial stresses found on the laminate in the reference beams, obtained from the strains measured along the surface, are shown in Fig. 3, for increasing $F$ and both GFRP widths. The stresses are considerably higher in the case of bending ( $20 \mathrm{~mm}$ [0.787 in.]), reflecting a cross section that is four times smaller, and the trend of the curves does not differ significantly.

The load transferred to the laminate at low values of external $F$ varies almost linearly along a short bonded length. Increasing $F$, the force distribution becomes nonlinear and shows local intermediate maxima and local debonding near the maximum capacity $F_{\max }$ due to cracking. The length of transmission of the force to concrete also increases.

Stresses after 10,000 hours of aging can be compared in Fig. 4 and 5 for both cycles, with some caution required due to the scattering of data, and the observed trends appear very similar. Segments with no transfer of load to concrete appear in both cases, corresponding to intermediate cracks. Changes of slope due to cracking are more pronounced for the 7.5 and $47.5^{\circ} \mathrm{C}\left(45.5\right.$ and $\left.117.5^{\circ} \mathrm{F}\right)$ cycles, which is partially attributed to material changes predictable from the larger decrease of $T_{g}$, as shown in Table 5 .

The reduction of axial stresses for strips of $20 \mathrm{~mm}$ (0.787 in.) was larger than for those with $80 \mathrm{~mm}$ (3.145 in.), in which the contribution of the laminate is smaller at failure and far from its full capacity, as the bond stresses confirm later on in the paper.

The exposure to artificial aging caused an increase of the bonded length along which there is force transfer to the concrete. Moving outwardly from the center, axial stress increases correspond to a decrease of "participation" of concrete or, physically, some local debonding, a feature translated by a visible increase on the areas of the plate that debond locally.

\section{Bond stresses}

The observed modes of rupture started at an intermediate flexural or flexural-shear crack and propagated toward the end of the laminate strips-a type of failure referred to as intermediate crack induced or interfacial debonding. This type of debonding is triggered by high stresses transmitted from the plates through the adhesive to the adjacent layer of concrete. It has been advanced that, in lab tests like the ones described, concrete fracture arises initially from high bond stresses due to tension stiffening in the cracked concrete. ${ }^{17}$ The intermediate cracking failure is thought to occur more often for large shear spans and relatively thin FRP reinforcement-for example, being reported in References 18 and 19. The interpretation of the changes on values of the bond stresses has to attend to aspects such as plasticization of the resin and better distribution of the transmitted force at the interface to the existence or not of consecutive cracks at the location where the measurement of the strains is made.

The bond stresses for beams with strips of $20 \mathrm{~mm}(0.787 \mathrm{in}$.) decreased with aging time, as seen in Tables 7 to 9. The 7.5 and $47.5^{\circ} \mathrm{C}\left(45.5\right.$ and $\left.117.5^{\circ} \mathrm{F}\right)$ cycles caused a reduction of the average maximum value from 6.49 to $4.60 \mathrm{MPa}$ $(6112.96 \mathrm{lbf})$ at 10,000 hours, whereas the freezing-andthawing aging caused a reduction to $4.82 \mathrm{MPa}(6112.96 \mathrm{lbf})$ at 3000 hours and $5.64 \mathrm{MPa}(6112.96 \mathrm{lbf})$ at 10,000 hours.

For the beams with strips of $w=80 \mathrm{~mm}$ (3.150 in.), (7.5 and $47.5^{\circ} \mathrm{C}$ [ 45.5 and $\left.117.5^{\circ} \mathrm{F}\right]$ cycles), the decrease found at 3000 hours was $26 \%$, whereas at 10,000 hours, the reduction was from $2.25 \mathrm{MPa}$ (326.33 psi), calculated from Table 7, to $2.09 \mathrm{MPa}(303.13 \mathrm{psi})$ - that is, only $7 \%$. For freezing-andthawing conditioning and shear-type cracking, the reduction 

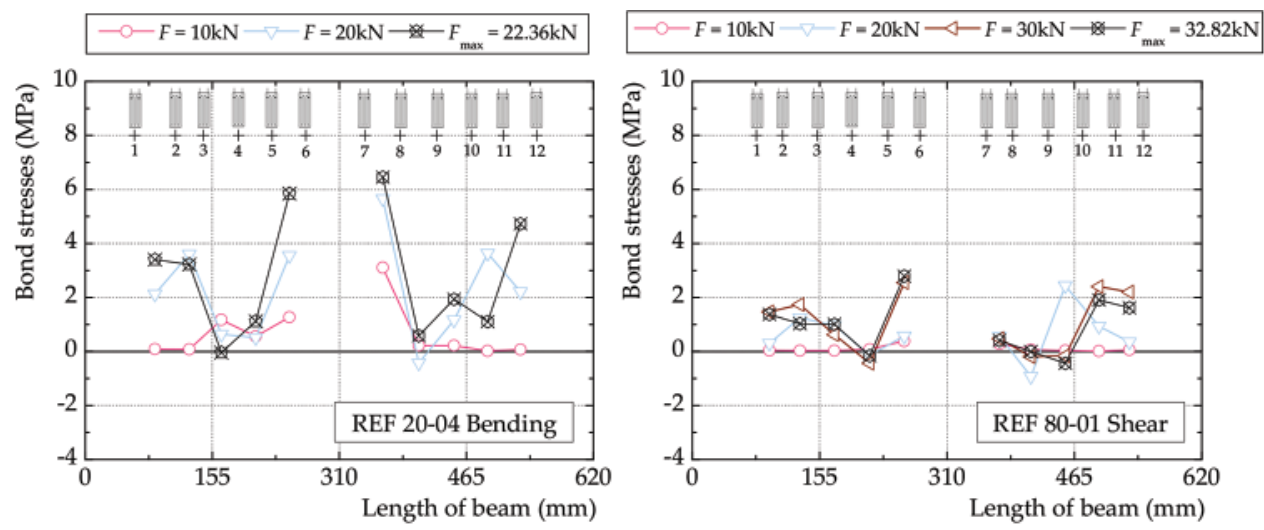

Fig. 6-Bond stresses for $\mathrm{w}=20 \mathrm{~mm}(0.787 \mathrm{in}$.$) and \mathrm{w}=80 \mathrm{~mm}(3.150 \mathrm{in}$.) and increasing external loading of reference beams. Note: $1 \mathrm{MPa}=145.0377 \mathrm{psi}$.)
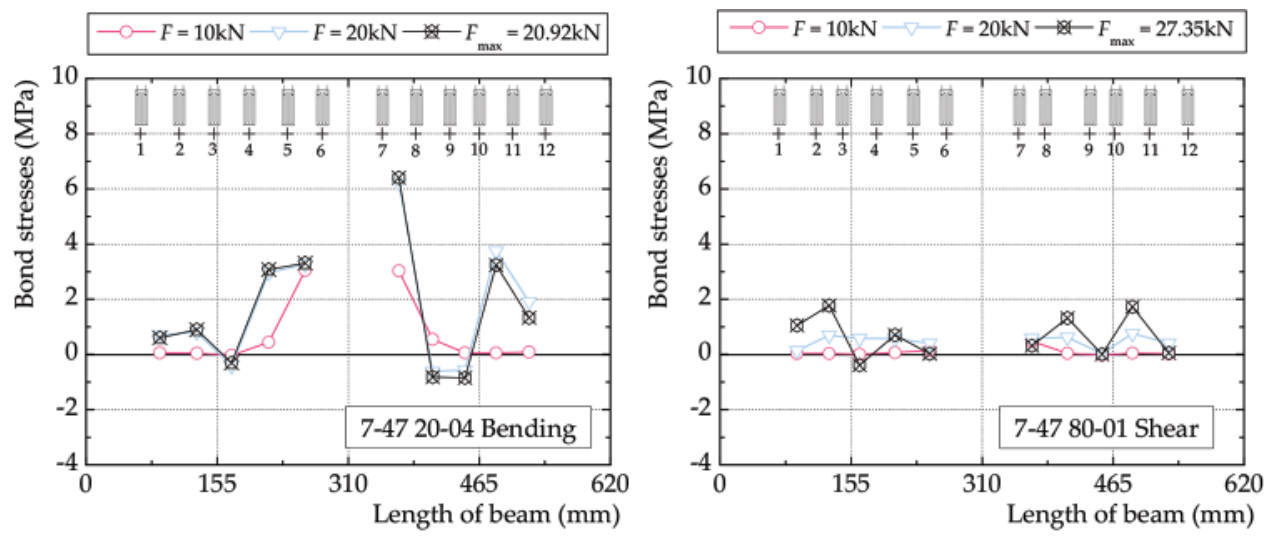

Fig. 7-Bond stresses for $\mathrm{w}=20 \mathrm{~mm}(0.787 \mathrm{in}$.$) and \mathrm{w}=80 \mathrm{~mm}(3.150 \mathrm{in}$.$) , and increasing$ external load. After 3000 hours of cycles 7.5 and $47.5^{\circ} \mathrm{C}\left(45.5\right.$ and $\left.117.5^{\circ} \mathrm{F}\right)$. (Note: $1 \mathrm{MPa}$ $=145.0377 \mathrm{psi} ; 1 \mathrm{~mm}=0.03937 \mathrm{in}$.)
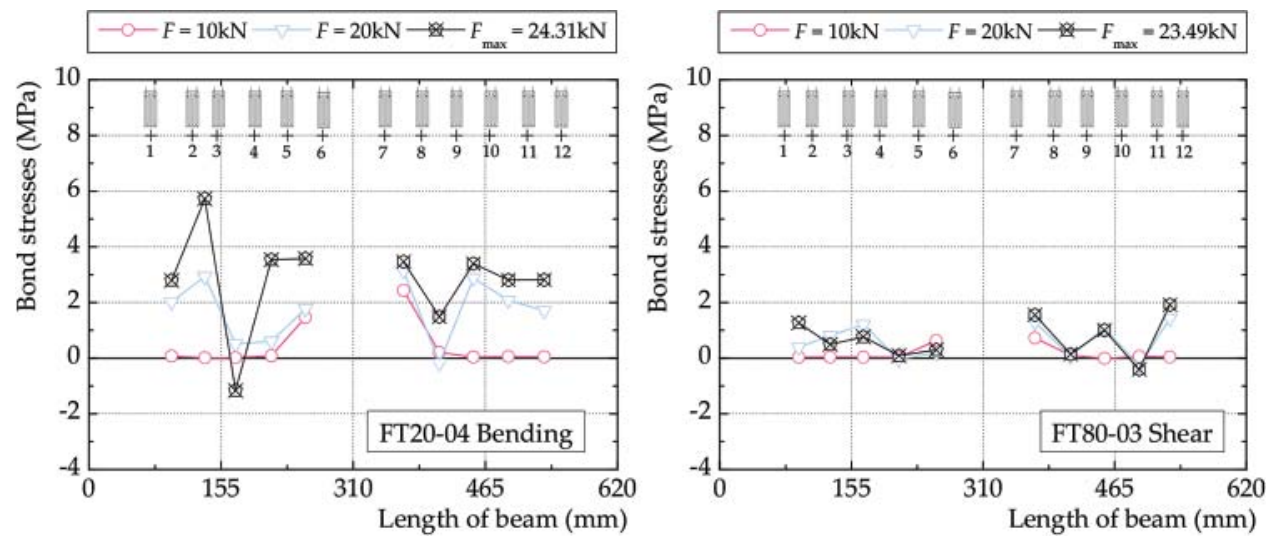

Fig. 8-Bond stresses for increasing external load for $\mathrm{w}=20$ and $80 \mathrm{~mm}(0.787$ and 3.150 in.). After 3000 hours of cycles -10 and $30^{\circ} \mathrm{C}\left(14\right.$ and $\left.86^{\circ} \mathrm{F}\right)$. (Note: $1 \mathrm{MPa}=$ $145.0377 \mathrm{psi} ; 1 \mathrm{~mm}=0.03937 \mathrm{in}$.)

was more pronounced at 3000 hours when it averaged 1.61 MPa (233.51 psi), whereas at 10,000 hours, the maximum bond stress lowered $17 \%$ to $1.86 \mathrm{MPa}(269.77 \mathrm{psi})$.

Figures 6 to 8 display the space distribution of bond stresses associated with consecutive levels of the external load $F$, for the reference beams, as well as for the specimens after aging, at 3000 hours, for both types of temperature cycles and both cases of $w=20$ and $80 \mathrm{~mm}(0.787$ and
3.150 in.) strips of GFRP. Figure 9 shows the results for 7.5 and $47.5^{\circ} \mathrm{C}\left(45.5\right.$ and $\left.117.5^{\circ} \mathrm{F}\right)$ after 10,000 hours.

\section{Observed failure modes}

The modes of failure showed slight changes after the environmental conditioning imposed.

Prior to artificial aging, the detachment of the GFRP strip is preceded by nucleation and coalescence of small cracks - some of which lead to the formation of visible 

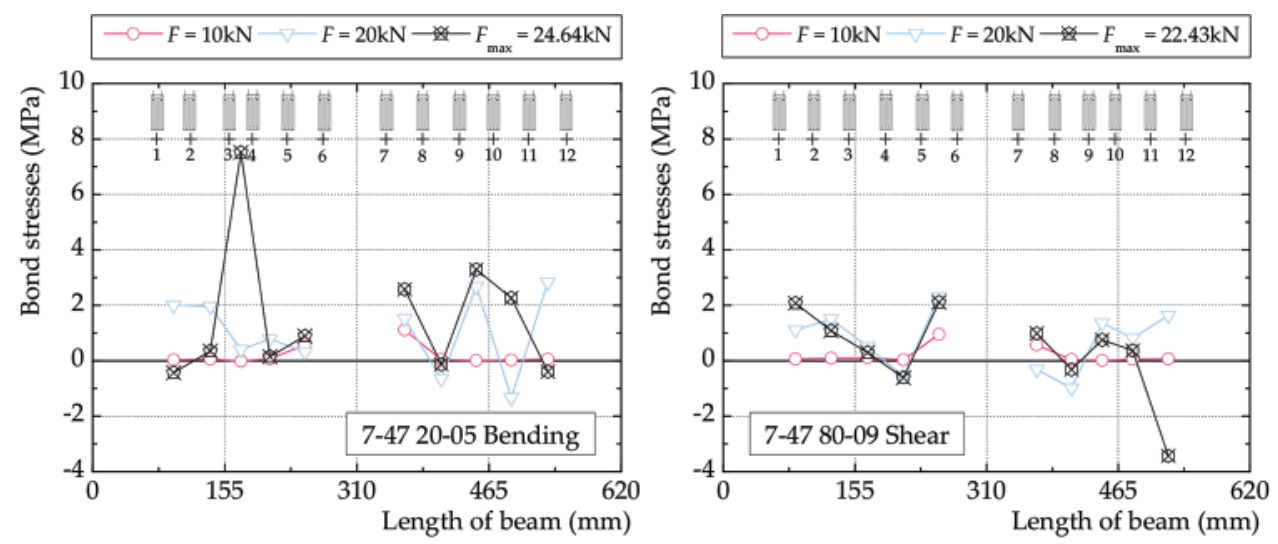

Fig. 9-Bond stresses for $\mathrm{w}=20 \mathrm{~mm}(0.787 \mathrm{in}$.$) and \mathrm{w}=80 \mathrm{~mm}(3.150 \mathrm{in}$.$) and increasing$ values of external load. Cycles 7.5 and $47.5^{\circ} \mathrm{C}\left(45.5\right.$ and $\left.117.5^{\circ} \mathrm{F}\right)$ at 10,000 hours. (Note: $1 \mathrm{MPa}=145.0377 \mathrm{psi} ; 1 \mathrm{~mm}=0.03937 \mathrm{in}$.)
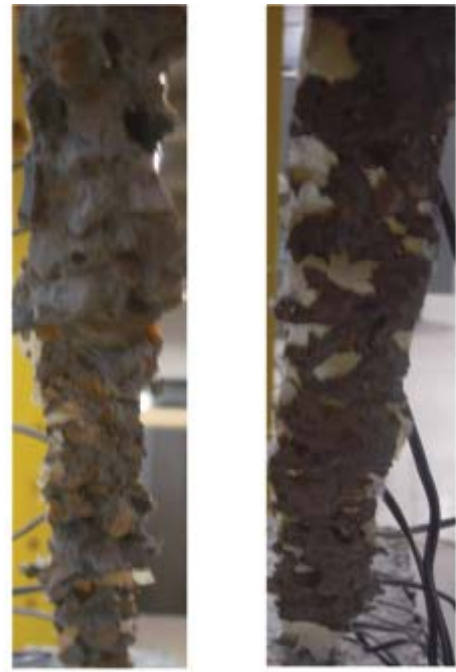

$3000 \mathrm{~h}$

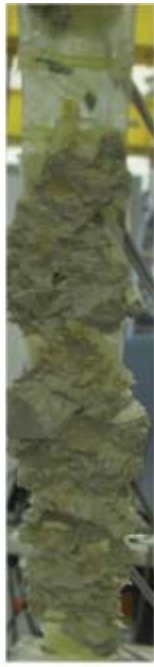

$10000 \mathrm{~h}$

Fig. 10-Strips of $20 \mathrm{~mm}$ (0.787 in.). Failure surfaces. Typical reference case and after 3000 hours and 10,000 hours of cycles 7.5 and $47.5^{\circ} \mathrm{C}\left(45.5\right.$ and $\left.117.5^{\circ} \mathrm{F}\right)$.

cracks, at least having one of them propagating rapidly and characterizing failure. In the case of induced cracking by flexure, a major, central crack and the central notch on the soffit create a post-failure system that, independently of the loading, approximates the two-block specimens hinged at the top that were used in previous studies. ${ }^{16}$

The intermediate crack (IC) debonding process generally started in the concrete layer adjacent to the FRP-concrete interface. The ensuing detachment of the $20 \mathrm{~mm}$ (0.787 in.) wide strip was associated with tensile rupture of the concrete adjacent to the interface, both in the reference specimens and in those aged for 3000 and 10,000 hours under the 7.5 and $47.5^{\circ} \mathrm{C}\left(45.5\right.$ and $\left.117.5^{\circ} \mathrm{F}\right)$ cycles (Fig. 10).

A different failure took place after the formation of major diagonal cracks for $w=80 \mathrm{~mm}$ (3.150 in.) and is reflected by partial adhesive detachment of the GFRP strip and displayed in Fig. 11, where some regions where separation took place without rupture in the concrete substrate can be recognized.

The failures observed after stages of freezing-and-thawing cycles were associated with cohesive failure where, again, the tensile strength of concrete was lower than the adhesive resistance at the interface. Figure 12 shows representative
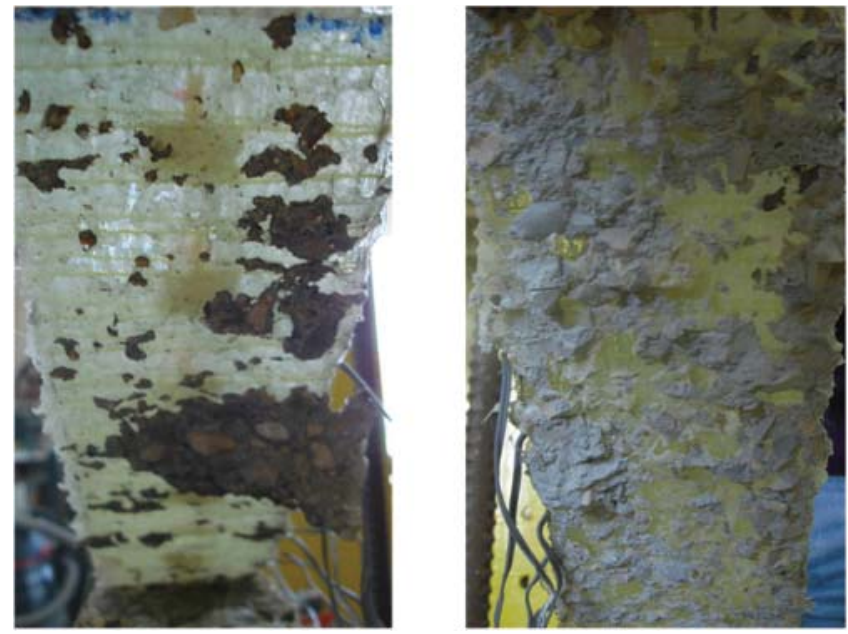

Fig. 11-Strips of $80 \mathrm{~mm}$ (3.150 in.). Failure surfaces after 3000 hours, 10,000 hours $\left(7.5\right.$ and $47.5^{\circ} \mathrm{C}[45.5$ and $\left.\left.117.5^{\circ} \mathrm{F}\right]\right)$ cycles.
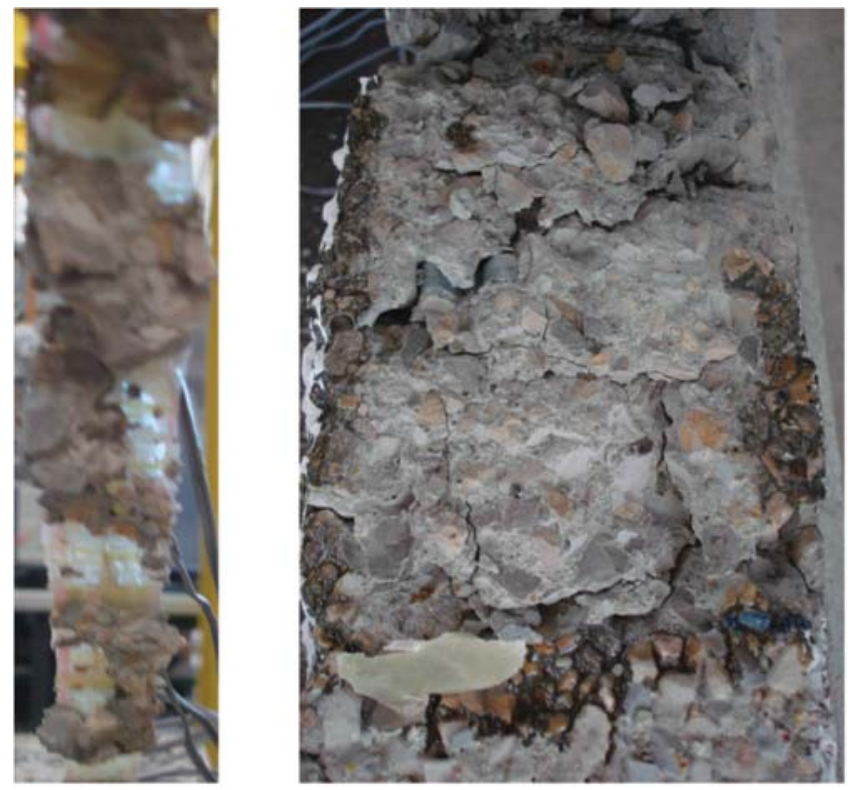

Fig. 12-Failure surfaces after 10,000 hours. Cycles -10 and $30^{\circ} \mathrm{C}\left(14\right.$ and $\left.86^{\circ} \mathrm{F}\right)$. Strips 20 and $80 \mathrm{~mm}(0.787$ and 3.150 in.). 

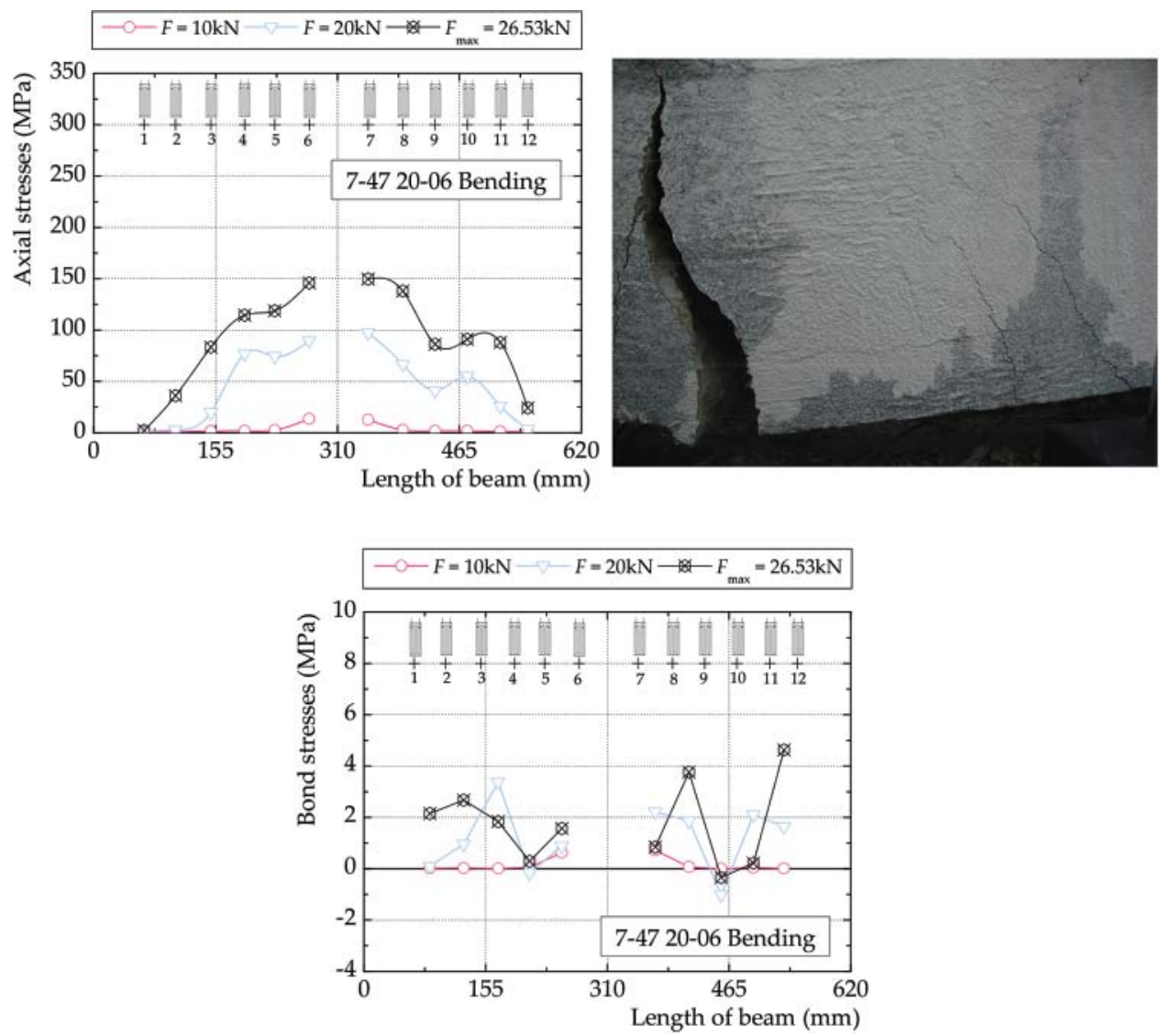

Fig. 13-Axial and bond stresses of beam and picture of right-hand side of specimen after failure at 10,000 hours of 7.5 and $47.5^{\circ} \mathrm{C}\left(45.5\right.$ and $\left.117.5^{\circ} \mathrm{F}\right)$ cycles. (Note: $1 \mathrm{MPa}=$ $145.0377 \mathrm{psi} ; 1 \mathrm{~mm}=0.03937 \mathrm{in}$.)

pictures for $w=20$ and $80 \mathrm{~mm}(0.787$ and 3.150 in.) and 10,000 hours.

Figure 13 shows axial stresses on beam 7-47-20-06 Bending

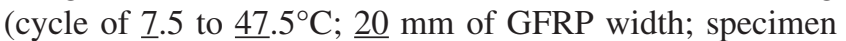
number 6) that failed for $F_{\max }=26.53 \mathrm{kN}$ (5.94 kip). The curves show the axial stress distribution and the bond stresses for successive stages of external load $F=10.20 \mathrm{kN}$ (2.29 kip) and $F_{\max }$.

The existence of a major crack was captured by one of the strain gauges, and is detected by the leveling of the curve of axial stresses for $F_{\max }$ and/or by the negative stress on the corresponding bond stress curve. The crack that occurred precisely where the strain gauge was placed is one of the two clearly seen on the picture, also shown in Fig. 13.

\section{CONCLUSIONS}

- GFRP laminates subjected to the temperature cycles suffered an initial increase of the axial deformability of up to $16 \%$ and a reduction of the ultimate tensile strength below $5 \%$, for both cycles.

- Shear-bending type of cracking and IC debonding mode of beams were triggered by the stronger external strengthening (strip width $w=80 \mathrm{~mm}$ [3.150 in.]) that prevented failure associated with bending.

Intermediate bond failures induced by shear-flexural or flexural-only cracking are different and also differ from the observed behavior recorded in studies where the presence of a midspan hinge originated a different stress field and debonding. ${ }^{20}$
The strains measured on the GFRP and the calculated bond stresses were significantly lower for the same external load, when the external strip was wider ( $w=80 \mathrm{~mm}$ [3.150 in.]).

The load-carrying capacity of the beams increased significantly both with the strips of $w=20 \mathrm{~mm}(0.787 \mathrm{in}$.) and $w=80 \mathrm{~mm}$ (3.150 in.), when compared with that of control specimens.

The length of bond transfer was longer for the shearbending induced failure.

- The three-point tests of artificially aged specimens, subjected to 24 hours cycles of frezeing-and-thawing type or at cycles between 7.5 and $47.5^{\circ} \mathrm{C}$ ( 45.5 and $117.5^{\circ} \mathrm{F}$ ), revealed the following after 3000 and 10,000 hours of aging:

The bond stresses and the axial forces on the laminates, for the same value of the external loading, decreased more markedly after the freezing-and-thawing cycles.

The decrease of capacity to carry external load was more noticeable for the specimens with $w=80 \mathrm{~mm}$ (3.150 in.) and for the 7.5 and $47.5^{\circ} \mathrm{C}\left(45.5\right.$ and $\left.117.5^{\circ} \mathrm{F}\right)$ cycles, reaching approximately $20 \%$.

The failure mechanisms did not show great changes, being of cohesive type except in the case of $w=80 \mathrm{~mm}$ (3.150 in.) and 7.5 and $47.5^{\circ} \mathrm{C}\left(45.5\right.$ and $\left.117.5^{\circ} \mathrm{F}\right)$ when separation of the strip at the interface was found.

The bond length was expected to increase, but the low values of the measurements near the supports after aging did not confirm that expectation.

- Different mechanisms of material and structural deterioration are triggered at different temperatures. More studies varying temperature and period of 
incidence are necessary to cover that aspect. In general, further data regarding performance of structural members externally strengthened with GFRP or CFRP over extended time periods are required, especially to study eventual synergetic incidence and behavior under stress. Also, the correlation between number of layers, aging, and bond slip deserve further attention before results can be conclusive and recommendations made for insertion on Codes.

\section{ACKNOWLEDGMENTS}

The studies were partially financed by Fundação para a Ciência e Tecnologia through Project DUST - PTDC/ECM/100538/2008. This help is acknowledged. The detailed comments by one of the reviewers are also acknowledged.

\section{REFERENCES}

1. Karbhari, V. M.; Chin, J. W.; and Reynaud, D., "Critical Gaps in Durability Data for FRP Composites in Civil Infrastructure," Proceedings, 45th International SAMPE Symposium and Exhibition, V. 45, May 21-25, 2000, Long Beach, CA, pp. 549-563.

2. Kajorncheappunngam, S.; Gupta, R. K.; and GangaRao, H. V. S., "Effect of Aging Environment on Degradation of Glass-Reinforced Epoxy," Journal of Composites for Construction, ASCE, V. 6, No. 1, Feb. 2002, pp. 61-69.

3. Karbhari, V. M.; Chin, J. W.; Hunston, D.; Benmokrane, B.; Juska, T.; Morgan, R.; Lesko, J. J.; Sorathia, U.; and Reynaud, D., "Durability Gap Analysis for Fiber-Reinforced Polymer Composites in Civil Engineering," Journal of Composites for Construction, ASCE, V. 7, No. 3, 2003, pp. 238-247.

4. Green, M. F.; Bisby, L. A.; Beaudoin, Y.; and Labossière, P., "Effect of Freeze-Thaw Cycles on the Bond Durability between Fiber Reinforced Polymer Plate Reinforcement and Concrete," Canadian Journal of Civil Engineering, V. 27, No. 5, 2000, pp. 949-959.

5. Elbadry, M. M.; Abdalla, H.; and Ghali, A., "Effects of Temperature on the Behavior of Fiber Reinforced Polymer Reinforced Concrete Members: Experimental Studies," Canadian Journal of Civil Engineering, V. 27, No. 5, 2000, pp. 993-1004.

6. Aiello, M. A., and Ombres, L., "Environmental Effects on the Mechanical Properties of Glass-FRP and Aramid-FRP Rebars," Mechanics of Composite Materials, V. 36, No. 5, 2000, pp. 395-398.
7. Katz, A.; Berman, N.; and Bank, L. C., "Effect of High Temperature on Bond Strength of FRP Rebars," Journal of Composites for Construction, ASCE, V. 3, No. 2, 1999, pp. 77-81.

8. Leone, M.; Matthys, S.; and Aiello, M. A., "Effect of Elevated Service Temperature on Bond between FRP Systems and Concrete," Composites. Part B, Engineering, V. 40, 2009, pp. 85-93.

9. CEB-FIP Task Group 9.3, "Externally Bonded FRP Reinforcement for RC Structures," Comité Euro-International du Béton Bulletin 14, 2001, $130 \mathrm{pp}$.

10. Ren, H.; Hu, A.; and Zhao, G., "Freeze-Thaw Resistance Behavior of Bonded Joints between FRP and Concrete," Journal of Dalian University of Technology, V. 43, No. 4, 2003, pp. 495-499.

11. Fava, G.; Mazzotti, C.; Poggi, C.; and Savoia, M., "Durability of FRP-Concrete Bonding Exposed to Aggressive Environment," FRPRCS-8, University of Patras, Patras, Greece, July 16-18, 2007, pp. 73-81.

12. Mukhopadhyaya, P.; Swamy, R. N.; and Lynsdale, C. J., "Influence of Aggressive Exposure Conditions on the Behaviour of Adhesive Bonded Concrete-GFRP Joints," Journal of Construction and Building Materials, V. 12 , No. 8, 1998, pp. 427-446.

13. Silva, M. A. G., and Biscaia, H., "Degradation of Bond between FRP and RC Beams," Composite Structures, V. 85, No. 2, 2008, pp. 166-174.

14. Silva, M. A. G., "Aging of GFRP Laminates and Confinement of Concrete Columns," Composite Structures, V. 85, No. 1, 2007, pp. 97-106.

15. ASTM D3039/D3039M, "Standard Test Method for Tensile Properties of Polymer Matrix Composite Materials," ASTM International, West Conshohocken, PA, 2007, 13 pp.

16. "UV Curable Monomers Properties: Shrinkage and Glass Transition," SARTOMETER Application Bulletin, 2003, pp. 1-6.

17. Sebastian, W. M., "Significance of Midspan Debonding Failure in FRP-Plated Concrete Beams," Journal of Structural Engineering, ASCE, V. 127, No. 7, 2001, pp. 792-798.

18. Smith, S. T., and Teng, J. G., "FRP-Strengthened RC Beams-I: Review of Debonding Strength Models," Engineering Structures, V. 24, No. 4, 2002, pp. 385-395.

19. Owen, R., and Rizkalla, S. H., "Experimental Study of Intermediate Crack Debonding in Fiber-Reinforced Polymer Strengthened Beams," ACI Structural Journal, V. 105, No. 1, Jan.-Feb. 2008, pp. 41-50.

20. Silva, M. A. G., and Biscaia, H., "Effects of Exposure to Saline Humidity on Bond between GFRP and Concrete," Composite Structures, V. 93 , No. 1, 2010, pp. 216-224. 
NOTES: 